•编者按・

\title{
多学科融合、多尺度探索
}

一一植物区系地理研究的新趋势

\author{
孙 航
}

(中国科学院昆明植物研究所东亚植物多样性与生物地理学重点实验室, 昆明 650201)

\section{Multi-disciplinary integration and multi-scale exploration: a new trend in the study of Floristic Geography}

\section{Hang Sun}

Key Laboratory for Plant Diversity and Biogeography, Kunming Institute of Botany, Chinese Academy of Sciences, Kunming 650201

植物区系地理学(Floristic Geography)是以植物 分类学为基础, 从空间格局(地理分布)上来探讨地 球上或一定区域内植物的构成及其地理格局形成 和起源演化过程的学科。当今的植物区系地理学研 究正从两大方面发展: 宏观上从地质历史一生态环 境-植物群落-植物区系及大尺度空间格局方面探 讨区系地理格局的成因; 微观上从生命之树-物种 形成一分子机制(基因组进化)揭示区系地理成分的 起源及进化机制; 或是二者(宏、微观)结合精确地 揭示植物区系的形成演变(物种形成)以及空间分异 (区系分区)。本专辑共收录了12篇有关植物区系或 植物区系地理研究的论文, 包括了植物区系形成的 地质背景、系统发育在植物区系研究中的应用、亲 缘地理、细胞地理、植物区系格局以及区系研究的 趋势及展望等, 在一定程度上反映了我国植物区系 地理的研究趋势和方向。

在植物区系形成的地质背景方面, 周浙昆等 (2017)总结了新生代以来中国境内的主要地质事件 并通过亚热带常绿阔叶林主要组成成分(如壳斗科、 樟科、木兰科、豆科、金缕梅科等)和子遗特有成分 地质历史的变迁, 讨论了若干重要地质事件如古新 世-始新世极热事件、青藏高原隆升、季风气候形 成、干旱带演变和第四纪冰期等对生物多样性的影 响, 为植物区系形成与演变提供了重要的地质背 景。刘杰等(2017)综述了地质历史和气候变化对青
藏高原及邻近地区植物多样性演化和维持的影响, 总结了当前的研究进展, 并对未来研究中值得关注 的问题进行了展望。

在结合系统发育研究植物区系时空格局的形 成方面，彭丹晓等(2017)从 3 个方面总结了区域生命 之树在植物区系研究中的应用: (1)在时间维度上, 通过生命之树类群的分化时间和进化速率估算, 反 映区系演化历史，揭示区系的时间分化格局；(2)在 空间维度上, 结合系统发育信息与物种分布数据, 揭示区系内生物多样性的空间格局, 并在此基础上 进行区系分区; (3)整合生物地理信息和气候环境数 据, 分析区系中生物类群对古地理事件以及气候变 化的响应机制, 以揭示形成现存生物多样性格局的 生态、地理和历史因素。李嵘和孙航(2017)基于云 南种子植物 1,983 个属的系统发育关系, 结合其地 理分布，从进化历史的角度分析了不同地理单元的 分类群组成、系统发育组成及其相似性, 探讨了各 个地理单元的系统发育结构及地理单元间的系统 发育相似性。慈秀芹和李捷(2017)讨论了系统发育 多样性的概念、测度方法以及在植物区系研究和生 物多样性保护中的应用, 也强调了DNA条形码研究 促进了系统发育多样性的发展, 为构建解决能力较 好的宏系统发育树提供了可能。

在结合亲缘地理研究植物区系形成和分化方 面, 邱英雄等(2017)分析比较了近年来东亚第三纪

*通讯作者 Author for correspondence. E-mail: sunhang@mail.kib.ac.cn 
子遗植物的种群遗传学与亲缘地理学的研究结果, 从暖温带落叶林类群的东西谱系分化、温带植物类 群的南北谱系分化与物种形成、中国-日本谱系分 化、中国大陆-台湾间断分布植物类群的谱系分化 以及西北干旱带植物类群的谱系分化等方面总结 了它们的谱系地理格局式样, 分析了其形成的地史 背景和气候成因。并指出基因组数据和生物地理模 型的使用以及群落水平的整合亲缘地理学研究已 成为未来的研究方向。

在植物区系地理格局形成方面，沈泽昊等 (2017)整合了中国境内 14座主要山地的高山植物区 系数据, 重点分析了其种子植物区系地理成分的构 成、不同山地之间的相似性及其环境和空间相关因 素。文章指出中国山地的高山带分布着物种丰富的 种子植物区系, 其地理分异显示北热带和东亚成分 自南向北减少而北温带成分增加, 自西向东古地中 海成分减少、北温带成分增加，而东亚成分在中部 达到最大值, 地理距离的隔离是高山植物区系分异 的首要因素, 高山带的面积大小也影响到其区系成 分的构成, 夏季热量是影响中国高山植物区系地理 分异的首要气候因子等。朱华(2017)研究了中国南 部的热带植物区系, 指出中国的热带地区种子植物 区至少有227科2,181属12,844种，区系构成以热带 分布属占优势, 并以热带亚洲分布属所占比例最 大, 标志着其热带边缘性质和具有热带亚洲植物区 系的特点; 由于不同地区地质历史及生态环境的差 异，中国热带植物区系在不同地区的组成和地理成 分也有一定差异, 其成因与喜马拉雅山脉隆升过程 中发生的地质事件有关。

在细胞地理研究方面, 王家坚等(2017)收集了 青藏高原与横断山的染色体资料, 并按科属及其分 布型、生活型以及海拔分布等各个方面进行统计分 析, 结果表明新多倍化在该地区只约占 $23 \%$ 的比例, 远低于其他高山地区，其中低基数的二倍体占有近 一半的比例(43.3\%), 反映了二倍体水平上的染色
体结构和核型进化是本地区物种分化的另一重要 机制。

在植物区系地理研究的趋势及展望方面，孙航 等(2017)综述了植物区系地理学的研究现状、存在 的问题和今后的发展趋势, 指出需加强对植物区系 薄弱或空白地区的调查, 补充和完善植物标本的详 细信息，提高标本鉴定的准确性。同时还指出，植 物区系地理学的研究步入了多学科融合交叉、综合 研究分析的时代: 一方面, 利用物种信息数据库, 融合生态学、古植物学以及地质历史等探讨区系空 间地理格局的成因; 另一方面结合系统发育、分子 系统进化(甚至到进化基因组学)、生命之树以及分 子生物地理学等揭示区系的起源和进化。同时, 各 学科的快速发展, 产生了大量的数据, 新的分析方 法或新理论的出现和运用，使得植物区系地理研究 也进入了大数据时代, 进而使得植物区系地理学由 定性的现象认识和描述, 逐步深入到了定量地探索 机理和形成时代。张明理等(2017)总结了西北干旱 区和中亚植物区系地理研究现状, 指出西北干旱区 作为中亚干旱区的东部，应该结合西部的中亚五 国，在一个自然地理区域的基础上研究其区系地 理, 才有更广泛的地理研究意义; 同时强调分子系 统发育和生物地理研究对区系地理研究的意义和 潜力。

总之, 本专辑论文在一定程度上反映出我国的 植物区系地理学研究已经步入了多学科融合交叉、 综合研究分析的新时代。随着学科的快速深入发展 和相互渗透，植物区系地理学的研究也正日益成为 生物多样性或生物地理学研究的热点领域。中国是 全球植物多样性最为丰富的国家之一, 也是解决许 多生物地理学或进化生物学重大理论问题的关键 地区，植物区系地理的研究方兴未艾。

文中引用的文献见附录 1(http://www.biodiversity-science.net/fileup/PDF/2017035-1.pdf) 
孙航. 多学科融合、多尺度探索一一植物区系地理研究的新趋势. 生物多样性, 2017, 25(2): 109-110. http://www.biodiversity-science.net/CN/10.17520/biods.2017035

\section{附录1 参考文献}

Ci XQ, Li J (2017) Phylogenetic diversity and its application in floristics and biodiversity conservation. Biodiversity Science, 25, 175-181. (in Chinese with English abstract) [慈 秀芹, 李捷 (2017) 系统发育多样性在植物区系研究与 生物多样性保护中的应用. 生物多样性, 25, 175-181.]

Li R, Sun H (2017) Phylofloristics: a case study from Yunnan, China. Biodiversity Science, 25, 195-203. (in Chinese with English abstract) [李嵘, 孙航 (2017) 植物系统发育区系 地理学研究: 以云南植物区系为例. 生物多样性, 25 , 195-203.]

Liu J, Luo YH, Li DZ, Gao LM (2017) Evolution and maintenance mechanisms of plant diversity in the Qinghai-Tibet Plateau and adjacent regions: retrospect and prospect. Biodiversity Science, 25, 163-174. (in Chinese with English abstract) [刘杰, 罗亚皇, 李德铢, 高连明 (2017) 青藏高 原及毗邻区植物多样性演化与维持机制: 进展及展望. 生物多样性, 25, 163-174.]

Peng DX, Lu LM, Chen ZD (2017) Regional tree of life and its application in floristic studies. Biodiversity Science, 25, 156-162. (in Chinese with English abstract) [彭丹晓, 鲁丽 敏, 陈之端 (2017) 区域生命之树及其在植物区系研究 中的应用. 生物多样性, 25, 156-162.]

Qiu YX, Lu QX, Zhang YH, Cao YN (2017) Phylogeography of East Asia's Tertiary relict plants: current progress and future prospects. Biodiversity Science, 25, 136-146. (in Chinese with English abstract) [邱英雄, 鹿启祥, 张永华, 曹亚男 (2017) 东亚第三纪子遗植物的亲缘地理学: 现 状与趋势. 生物多样性, 25, 136-146.]

Shen ZH, Yang MZ, Feng JM, Li XH, Peng PH, Zheng Z (2017) Geographic patterns of alpine flora in China in relation to environmental and spatial factors. Biodiversity Science, 25, 182-194. (in Chinese with English abstract) [沈 泽吴, 杨明正, 冯建孟, 李新辉, 彭培好, 郑智 (2017)
中国高山植物区系地理格局与环境和空间因素的影响. 生物多样性, 25, 182-194.]

Sun H, Deng T, Chen YS, Zhou Z (2017) Current research and development trends in floristic geography. Biodiversity Science, 25, 111-122. (in Chinese with English abstract) [孙 航, 邓涛, 陈永生, 周卓 (2017) 植物区系地理研究现状 及发展趋势. 生物多样性, 25, 111-122.]

Wang JJ, Peng ZB, Sun H, Nie ZL, Meng Y (2017) Cytogeographic patterns of angiosperms flora of the Qinghai-Tibet Plateau and Hengduan Mountains. Biodiversity Science, 25, 218-225. [王家坚, 彭智邦, 孙航, 聂泽龙, 孟盈 (2017) 青藏高原与横断山被子植物区系演化的细 胞地理学特征. 生物多样性, 25, 218-225.]

Zhang ML (2017) A review on the floristic phytogeography in arid northwestern China and Central Asia. Biodiversity Science, 25, 147-155. (in Chinese with English abstract) [张明 理 (2017) 中国西北干旱区和中亚植物区系地理研究. 生物多样性, 25, 147-155.]

Zhou ZK, Huang J, Ding WN (2017) Responses of Chinese floristic communities to major geological events. Biodiversity Science, 25, 123-135. (in Chinese with English abstract) [周浙昆, 黄健, 丁文娜 (2017) 若干重要地质事件 对中国植物区系形成演变的影响. 生物多样性, 25, 123-135.]

Zhu H (2017) Tropical flora of southern China. Biodiversity Science, 25, 204-217. (in Chinese with English abstract) [朱 华 (2017) 中国南部热带植物区系. 生物多样性, 25, 204-217.] 